\title{
BPJS KESEHATAN DALAM PERSPEKTIF EKONOMI SYARIAH
}

\author{
I t a n $g$ \\ IAIN Sultan Maulana Hasanuddin Banten \\ Jl. Jenderal Sudirman No. 30 Serang, Banten \\ E-mail: itangfauzihasim@gmail.com
}

\begin{abstract}
BPJS Health Insurance in Islamic Economic Perspectives. This article provides answer to the MUI statements that BPJS is inconsistent with the principles of sharia economics. First, a solution to avoid gharâr, where participants pay a monthly premium, but it is unclear how much they will receive. Second, the solution to avoid the element of gambling, where financial calculations can be profit or loss. Third, the solution of usury, when claims were received by participants of BPJS greater than the premium paid, therefore, it contains elements of usury and usury fadhl category. Meanwhile, when there is a delay of participants to pay premiums, BPJS establishes fines that is also included nasîah usury.
\end{abstract}

Keywords: BPJS health insurance, islamic economics, gharâr, gambling, usury

\begin{abstract}
Abstrak. BPJS Kesehatan dalam Perspektif Ekonomi Syariah. Artikel ini memberikan jawaban terhadap pernyataan MUI tentang BPJS tidak sesuai dengan prinsip ekonomi syariah. Pertama, solusi agar tidak terjadi gharâr, di mana peserta bayar premi bulanan namun tidak jelas berapa jumlah yang akan diterima. Kedua, solusi agar tidak terjadi unsur judi, di mana perhitungan keuangan bisa jadi untung atau bisa jadi rugi.Ketiga, solusi tentang riba, ketika klaim yang diterima peserta BPJS lebih besar dari premi yang dibayarkan. Hal tersebut mengandung unsur riba dan termasuk kategori riba fadhl.Sedangkan ketika terjadi keterlambatan peserta dalam membayar premi, BPJS menetapkan denda yang juga termasuk riba nasîah.
\end{abstract}

Kata kunci: BPJS kesehatan, ekonomi syariah, gharâr, judi, riba

\section{Pendahuluan}

Pada tanggal 1 januari 2014 mulai diberlakukan BPJS kesehatan di seluruh pelayanan kesehatan di Indonesia. ${ }^{1}$ Ujicoba BPJS sudah mulai dilaksanakan sejak tahun 2012 dengan rencana aksi dilakukan pengembangan fasilitas kesehatan dan tenaga kesehatan dan perbaikan pada sistem rujukan dan infrastruktur. Evaluasi jalannya jaminan kesehatan nasional ini direncanakan setiap tahun dengan periode per enam bulan dengan kajian berkala tahunan elitibilitas fasilitas kesehatan, kredensialing, kualitas pelayanan, dan penyesuaian besaran pembayaran harga keekonomian. Diharapkan, pada 2019 jumlah fasilitas kesehatan dan tenaga kesehatan mencukupi, distribusi merata, sistem rujukan berfungsi optimal, pembayaran dengan cara prospektif dan harga keekonomian untuk semua penduduk. Pelaksanaan UU BPJS melibatkan PT ASKES, PT ASABRI, PT

Naskah diterima: 18 Januari 2015, direvisi: 4 Februari 2015, disetujui untuk terbit: 10 Maret 2015.

${ }^{1}$ BPJS "BPJS Kesehatan"Artikel, Jln. Let. Jend. Suprapto Cempaka Putih Jakarta Pusat, 2014.
JAMSOSTEK dan PT TASPEN, di mana PT ASKES dan PT JAMSOSTEK beralih dari Perseroan menjadi Badan Publik mulai 1 Januari 2014. Sedangkan PT ASABRI dan PT TASPEN pada tahun 2029 beralih menjadi badan publik dengan bergabung ke dalam BPJS ketenagakerjaan.

Pelayanan kesehatan BPJS mempunyai sasaran dalam pelaksanaan akan adanya sustainibilitas operasional dengan memberi manfaat kepada semua yang terlibat dalam BPJS, pemenuhan kebutuhan medik peserta, dan kehati-hatian, serta transparansi dalam pengelolaan keuangan BPJS. Perlu perhatian lebih mendalam dalam pelaksanaan terhadap sistem pelayanan kesehatan (health care delivery sistem), sistem pembayaran (health care payment sistem) dan sistem mutu pelayanan kesehatan (health care quality sistem). Mengingat pelaksanaan BPJS dikeluarkan melalui Undang-Undang di mana bersifat mengatur sedangkan proses penetapan pelaksanaan diperkuat melalui surah keputusan atau ketetapan dari pejabat Negara yang berwenang seperti Peraturan Pemerintah dan Peraturan Presiden setidaknya minimal sepuluh regulasi turunan 
harus dibuat untuk memperkuat pelaksanaan BPJS.

Saat ini, masalah banyak yang muncul dari implementasi BPJS, yaitu:2 Pertama, sistem pelayanan kesehatan (health care delivery sistem), sistem ini di antaranya: (a) penolakan pasien tidak mampu di fasilitas pelayanan kesehatan hal ini dikarenakan PP No. 101/2012 tentang PBI jo. Perpres 111/2013 tentang Jaminan kesehatan hanya mengakomodasi 86,4 juta rakyat miskin sebagai PBI padahal menurut BPS (2011) orang miskin ada 96,7 juta. Pelaksanaan BPJS tahun 2014 didukung pendanaan dari pemerintah sebesar Rp 26 trliun yang dianggarkan di RAPBN 2014. Anggaran tersebut dipergunakan untuk Penerima Bantuan Iuran (PBI) sebesar Rp 16.07 trliun bagi 86,4 juta masyarakat miskin sedangkan sisanya bagi PNS, TNI dan Polri. Pemerintah harus secepatnya menganggarkan biaya kesehatan Rp 400 milyar untuk gelandangan, anak jalanan, penghuni panti asuhan, panti jompo dan penghuni lapas (jumlahnya sekitar 1,7 juta orang). Dan tentunya jumlah orang miskin yang discover BPJS kesehatan harus dinaikkan menjadi 96,7 juta dengan konsekuensi menambah anggaran dari APBN. b). Pelaksanaan di lapangan, pelayanan kesehatan yang diselenggarakan oleh PPK I (Puskesmas klinik) maupun PPK II (Rumah Sakit) sampai saat ini masih bermasalah. Pasien harus mencari-cari kamar dari satu RS ke RS lainnya karena dibilang penuh oleh RS, bukanlah hal yang baru dan baru sekali terjadi. ${ }^{3}$

Kedua, sistem pembayaran (health care payment sistem), sistem ini meliputi: (a) Belum tercukupinya dana yang ditetapkan BPJS dengan real cost, terkait dengan pembiayaan dengan skema INA CBGs dan kapitasi yang dikebiri oleh Permenkes No. 69/2013. Dikeluarkannya SE No. 31 dan 32 tahun 2014 oleh Menteri Kesehatan untuk memperkuat Permenkes No. 69 ternyata belum bisa mengurangi masalah di lapangan. (b) Kejelasan area pengawasan masih lemah baik dari segi internal maupun eksternal. Pengawasan internal seperti melalui peningkatan jumlah peserta dari 20 juta (dulu dikelola PT Askes) hingga lebih dari 111 juta peserta, perlu diantisipasi dengan perubahan sistem dan pola pengawasan agar tidak terjadi korupsi. Pengawasan eksternal, melalui pengawasan Otoritas jasa Keuangan (OJK), Dewan Jaminan Sosial Nasional

\footnotetext{
${ }^{2}$ Antia Tijan, "Analisa Kebijakan Undang-undang Implementasi BPJS 1 Januari 2014”, Magister Ilmu Keperawatan Universitas Indonesia, 2014.

${ }^{3}$ Rizka Syafaatul Udzma, "Evaluasi Jaminan Kesehatan Nasional Dalam Upaya Peningkatan Mutu Pelayanan Kesehatan di Indonesia”, Program Studi Ilmu Farmasi Sekolah Tinggi Ilmu Kesehatan Ngudi Waluyo, 2014, h. 10.
}

(DJSN) dan Badan Pengawas Keuangan (BPK) masih belum jelas area pengawasannya.

Ketiga, sistem mutu pelayanan kesehatan (health care quality sistem), sistem ini meliputi: (a) Keharusan perusahaan BUMN dan swasta nasional, menengah dan kecil masuk menjadi peserta BPJS Kesehatan belum terealisasi mengingat manfaat tambahan yang diterima pekerja BUMN atau swasta lainnya melalui regulasi turunan belum selesai dibuat. Hal ini belum sesuai dengan amanat Perpres No. 111/2013 (pasal 24 dan 27) mengenai keharusan pekerja BUMN dan swasta menjadi peserta BPJS Kesehatan paling lambat 1 Januari 2015. Dan regulasi tambahan ini harus dikomunikasikan secara transparan dengan asuransi kesehatan swasta, serikat pekerja dan Apindo sehingga soal Manfaat tambahan tidak lagi menjadi masalah. (b) Masih kurangnya tenaga kesehatan yang tersedia di fasilitas kesehatan sehingga peserta BPJS tidak tertangani dengan cepat.

Keempat, BPJS kesehatan belum ada kajian khusus mengenai kehalalannya menurut ekonomi syariah, sehingga menuai protes di kalangan umat Islam yang menuntut praktik ekonomi sesuai dengan agama yang dipeluknya.

Dari sejumlah persoalan tentang BPJS kesehatan ini penulis akan mengkaji lebih dalam lagi mengenai BPJS kesehatan terebut dalam persfektif ekonomi syariah.

\section{Sistem Penyaluran BPJS Kesehatan}

Kartu perlindungan sosial (KPS) adalah kartu yang diterbitkan oleh Pemerintah Indonesia dalam rangka program percepatan dan perluasan sosial (P4S). Dengan memiliki KPS, rumah tangga berhak menerima program-program perlindungan sosial, seperti: raskin dan bantuan siswa miskin (BSM), sesuai dengan ketentuan yang berlaku hingga tahun 2014. KPS memuat informasi nama kepala rumah tangga, nama pendamping kepala rumah tangga, nama anggota rumah tangga, alamat rumah tangga, dilengkapi dengan kode batang beserta nomor identitas KPS yang unik. ${ }^{4}$ Jumlah peserta BPJS cukup besar berdampak kepada aspek pendanaan yang harus disediakan oleh pemerintah. Pelaksanaan lebih lanjut program JKN dituangkan dalam pengalokasian dana jaminan kesehatan/JKN, sebesar Rp 33 Triliun

\footnotetext{
${ }^{4}$ Author Feny, "Syarat Mendapatkan Kartu Perlindungan Sosial", Dinas Tenaga Kerja dan Sosial/ Disnakersos (Gedung Dibaleka II Komplek Balaikota Depok Lantai 8, Jl. Margonda Raya No. 54 Depok, 2013.
} 
atau 3,7\% pada APBNP 2014. Implementasinya cukup luas mulai dariperencanaan, pelaksanaan, hingga pertanggungjawaban dan pengawasan dana jaminan kesehatan nasional. Dana tersebut disebut dengan dana kapitasi. ${ }^{5}$

Pertama, dana kapitasi. BPJS kesehatan menghimpun iuran yang dibayar oleh masyarakat yang telah mendaftarkan diri sebagai peserta program JKN. Selanjutnya BPJS, mendistribusikan anggaran jaminan kesehatan masyarakat secara kapitasi untuk mengoptimalkan pelayanan. Istilah kapitasi berasal dari kata kapital yang berarti kepala. Sistem kapitasi berarti cara perhitungan berdasarkan jumlah kepala yang terikat dalam kelompok tertentu. Dalam hal JKN ini, kepala berarti orang atau peserta atau anggotaprogram BPJS Kesehatan.

Pendistribusian dana BPJS secara kapitasi adalah suatu metode pembayaran untuk jasa pelayanan kesehatan di mana pemberi pelayanan kesehatan di FKTP menerima sejumlah tetap penghasilan per peserta, per periode waktu untuk pelayanan yang telah ditentukan. Hal ini dipertegas dengan Pasal 1 Angka (6) Peraturan Presiden Nomor 32 Tahun 2014 yang menyatakan bahwa dana kapitasi adalah besaran pembayaran per bulan yang dibayar di muka kepada fasilitas kesehatan tingkat pertama (FKTP) berdasarkan jumlah peserta yang terdaftar tanpa memperhitungkan jenis dan jumlah pelayanan kesehatan yang diberikan. ${ }^{6}$

Sebagaimana dinyatakan dalam Pasal 1 ayat (3) Perpres No. 32 Tahun 2014 Tentang Pengelolaan dan Pemanfaatan Dana kapitasi Jaminan Kesehatan Nasional pada Fasilitas Kesehatan Tingkat Pertama Milik Pemerintah Daerah, Fasilitas Kesehatan Tingkat Pertama yang selanjutnya disingkat FKTP adalah fasilitas kesehatan yang melakukan pelayanan kesehatan perorangan yang bersifat non spesialistis untuk keperluan observasi, diagnosis, perawatan, pengobatan, dan/atau pelayanan kesehatan lainnya. Fasilitas kesehatan yang dimaksud adalah tempat untuk melakukan pelayanan kesehatan yang dilakukan oleh Pemerintah, Pemerintah Daerah, dan/atau masyarakat. Dapat berupa praktik dokter perorangan, rumah sakit, dan puskesmas.

Kedua, pelaksanaan dana kapitasi. Pemerintah

\footnotetext{
${ }^{5}$ Ita Hartati, "Dana Kapitasi BPJS Kesehatan: Pelaksanaan dan Pertanggungjawabannya”, Balai Diklat Keuangan Makassar, 2014.

${ }^{6}$ Anynomous, Peraturan Presiden Nomor 32 Tahun 2014 Tentang Pengelolaan dan Pemanfaatan Dana Kapitasi Jaminan Kesehatan Nasional, 2014. h. 7.
}

berupaya supaya pengimplementasian JKN berlangsung semakin lebih baik, sehingga sejumlah regulasi dibuat, antara lain: Peraturan Presiden No 32 Tahun 2014 Tentang Pengalokasian dan Pemanfaatan Dana kapitasi Jaminan Kesehatan Tingkat Pertama (FKTP) milik Pemerintah dan dukungan biaya operasional FKTP Milik Pemerintah Daerah diterbitkan sebagai pedoman FKTP dalam menggunakan dana yang diberikan oleh BPJS. Untuk pedoman teknis pelaksanaan kegiatan FKTP yang berada pada Pemerintah Daerah, dibuat Surah Edaran Menteri Dalam Negeri Nomor 900/2280/ SJ Tanggal 5 Mei 2014 Tentang Petunjuk Teknis Penganggaran, Pelaksanaan dan Penatausahaan, serta Pertanggungjawaban Dana kapitasi Jaminan Kesehatan Nasional pada Fasilitas Kesehatan Tingkat Pertama Milik Pemerintah Daerah. Peraturan ini mengatur bagaimana tata cara pengelolaan dana kapitasi yang digelontorkan oleh Pemerintah melalui BPJS tersebut ke FKTP dapat berjalan dan digunakan sesuai dengan kaidah pengelolaan keuangan Negara yang baik dan benar.

Regulasi yang digulirkan Menteri Dalam Negeri melalui Surah Edaran Menteri Dalam Negeri Nomor 900/2280/SJ Tanggal 5 Mei 2014 membuat banyak Kepala Puskesmas, Kepala Dinas Kesehatan dan Pejabat Pengelolaan Keuangan Daerah/Bendahara Umum Daerah (BUD) menjadi ragu dan takut akan konsekuensi hukum terhadap cara penatausahaan dan pertanggungjawabannya. Hal tersebut terjadi karena sesuai dengan SE Mendagri tersebut. Dana kapitasi yang bersumber dari APBN/BPJS ditransfer langsung ke rekening bendahara Puskesmas/FKTP milik Pemerintah Daerah. Namun dana kapitasi tersebut harus tetap dicatatkan dalam laporan keuangan Pemerintah Daerah setempat meskipun aliran dana kapitasi tersebut tidak melalui rekening Bendahara Umum Daerah. Selanjutnya karena masuk dalam laporan keuangan Pemerintah Daerah maka pertanggungjawaban dana kapitasi tersebut menjadi objek pemeriksaan oleh Badan Pemeriksa Keuangan (BPK) dalam rangka pemeriksaan Laporan Keuangan Pemerintah Daerah.

Ketiga, tanggung jawab dana kapitasi. Regulasi aturan yang telah dikeluarkan oleh regulator (Perpres 32/2014, Permenkes 19/2014 dan SE Mendagri No. 900/2280/SJ membuka peluang tanggung jawab renteng. Tanggung jawab secara bersama ini akan berdampak pada masalah hukum, terlihat pada proses pelaporan pada pasal 8 (2) yang berbunyi: Bendahara Dana kapitasi JKN mencatat dan menyampaikan realisasi pendapatan 
serta belanja kepada Kepala FKTP, lalu Kepala FKTP menyampaikan hal tersebut kepada Kepala Satuan Kerja Perangkat Daerah (SKPD) Dinas bersangkutan dengan melampirkan Surah Pernyataan Tanggung Jawab. Sehingga timbul tanggung jawab renteng mulai dari Kepala FKTP, Kepala SKPD Kesehatan, Pejabat Pengelola Keuangan Daerah/BUD serta Bendahara Kapitasi. Maka menjadi pertanyaan siapa yang sesungguhnya harus bertanggungjawab penuh apabila terjadi kesalahan dalam pengelolaan Dana kapitasi di tingkat FKTP/Puskesmas.

Keempat, mekanisme transfer dana pemerintah. Ada beberapa sistem mekanisme klasifikasi uang/dana transfer APBN ke Pemerintah Daerah yang berjalan saat ini, antara lain: ${ }^{7}$ Pertama, sistem dana perbantuan artinya dana Pemerintah harus dipertanggungjawabkan/ di SPJ kan oleh Pemerintah Daerah ke Pemerintah Pusat. Untuk dana kapitasi cara ini cocok/sesuai tapi tidak fleksibel. Ketidakfleksibelan cara ini, dapat menghambat kecepatan pelayanan di FKTP.

Kedua, sistem masukan dana transfer pusat seperti dana alokasi umum, dana alokasi khusus dan dana dekonsentrasi ke APBD. Cara ini tidak cocok/ sesuai untuk Dana kapitasi karena akan jadi lebih kacau lagi, karena penganggarannya harus mendapat persetujuan DPRD.

Ketiga, sistem uang muka, tidak cocok di terapkan dalam penyaluran Dana kapitasi, karena semua harus ada kegiatan terlebih dahulu baru pencairan dana diajukan dan setelah disetujui.

Dari ketiga cara di atas tidak ada yang cocok dengan kebutuhan pembayaran biaya pelayanan kesehatan di FKTP. Sehingga pengambil kebijakan/regulator memformulasikan cara tertentu untuk bagaimana dana bisa tersebar dan tanpa hambatan sekaligus dapat dipertanggungjawabkan, yaitu dana kapitasi ditransfer langsung dari dana APBN/BPJS ke rekening bendahara dana kapitasi FKTP secara keseluruhan. Uang diberikan terlebih dahulu meskipun belum ada kegiatannya. Namun, peruntukannya sudah jelas dan diatur, yaitu maksimal 60\% untuk pembayaran jasa pelayanan kesehatan dan minimal $40 \%$ pembayaran untuk biaya operasional pelaksanaan kesehatan. Sebelum diundangkannya Peraturan Presiden (Perpres) Nomor 32 Tahun 2014 dan Permenkes Nomor 19 Tahun 2014, pembayaran Dana kapitasi oleh BPJS ke FKTP Pemerintah Daerah, periode 1 Januari sampai

\footnotetext{
${ }^{7}$ Ita Hartati, "Dana Kapitasi BPJS Kesehatan: Pelaksanaan dan Pertanggungjawabannya”, Balai Diklat Keuangan Makassar, 2014.
}

dengan 30 April 2014, dana kapitasi terlebih dahulu harus ditransfer atau masuk dulu ke kas daerah dan baru kemudian dapat digunakan setelah diusulkan dalam dokumen anggaran melalui RKA (Rencana Kerja Anggaran) dan DPA (Daftar Pelaksanaan anggaran). Proses seperti ini tentu menjadi hambatan tersendiri bagi FKTP milik pemerintah daerah untuk dapat segera memanfaatkan dana tersebut dalam memberikan pelayanan kesehatan.

Karena adanya hambatan di atas pemerintah membuat terobosan baru melalui Perpres 32/2004 dan Permenkes 19/2014. Dana kapitasi langsung dibayarkan BPJS Kesehatan ke FKTP milik Pemerintah Daerah melalui rekeningbendahara Dana kapitasi JKN pada FKTP. Dana kapitasi ini merupakan bagian dari rekening BUD yang diakui sebagai pendapatan yang dapat digunakan langsung untuk pembayaran pelayanan kesehatan peserta JKN pada FKTP meskipun aliran dananya tidak melalui rekening BUD. Tujuan dana tersebut ditransfer langsung masuk ke rekening bendahara Puskesmas/FKTP adalah supaya kegiatan kesehatan tidak terhambat. Sesuai aturan tata kelola keuangan Pemerintah Daerah, dana kapitasi yang diterima FKTP tersebut harus dicatat atau dibukukan. Kita ketahui bahwa sumber uang/dana kapitasi sebagian berasal dari iuran peserta yang disetor ke BPJS. Sebagaimana kaidah tata kelola dana pemerintah, semua uang yang terkait dengan keuangan negara harus dibukukan dan dibuatkan pelaporannya sebagai bentuk pertanggungjawaban FKTP. Pada prinsipnya semua layanan kesehatan pada FKTP harus segera dapat dibayarkan oleh bendahara Puskesmas, sehingga FKTP tidak ada hambatan/kendala dalam hal pelayanan menangani kasus-kasus kesehatan di lapangan. Skema aliran pertanggungjawaban dana kapitasi BPJS ditingkat Pemerintah Daerah.

Kelima, bendahara dana kapitasi. Dari dasar hukum tersebut di atas dapat terlihat arti penting keberadaan dan peran bendahara dalam keterlibatannya pada pengelolaan dana kapitasi. Berikut ini adalah hal-hal terkait dengan pengangkatan bendahara kapitasi: (a) Bendahara dana kapitasi JKN diangkat oleh Kepala Daerah atas usul PPKD untuk melaksanakan tugas kebendaharaan dalam rangka pengelolaan dan pemanfaatan Dana kapitasi JKN pada PPTK; (b) Bendahara Dana kapitasi JKN adalah pejabat fungsional; (c) Jabatan bendahara dana kapitasi JKN tidak boleh dirangkap oleh kuasa pengguna anggaran atau kuasa Bendahara Umum Negara /Daerah; (d) Bendahara dana kapitasi JKN dilarang melakukan, baik secara langsung maupun tidak langsung, kegiatan 
perdagangan, pengerjaan pemborongan dan penjualan jasa atau bertindak sebagai penjamin atas kegiatan/ pekerjaan/penjualan tersebut; (e) Bendahara Dana kapitasi JKN memiliki tugas dan fungsi kebendaharaan, yaitu:

- Menerima. Seorang bendahara dana kapitasi JKN menerima dan menatausahakan dengan baik aliran kas berupa dana kapitasi JKN dari BPJS.

- Menyimpan. Bendahara dana kapitasi JKN dalam melaksanakan tugasnya menggunakan rekening dana kapitasi JKN dalam menyimpan uangnya atas nama jabatannya (tidak diperkenankan atas nama pribadi) sebagai bagian dari rekening BUD.

- Membayarkan. Tugas fungsional bendahara dana kapitasi JKN melaksanakan pembayaran melalui persediaan uang tunai dan dapat dilakukan atas perintah pengguna anggaran/kuasa pengguna anggaran. Jika persyaratan tersebut di atas tidak terpenuhi, bendahara dana kapitasi JKN wajib menolak perintah pembayaran dari PA/ KPA, karena bendahara dana kapitasi JKN bertanggungjawab secara pribadi atas pembayaran yang dilaksanakan.

- Menatausahakan. Bendahara dana kapitasi JKN wajib menyelenggarakan pembukuan terhadap seluruh penerimaan dan pengeluaran meliputi seluruh transaksi dalam rangka pelaksanaan anggaran belanda dana kapitasi.

- Mempertanggungjawabkan. Bendahara dana kapitasi JKN wajib menyampaikan pertanggungjawaban atas pengelolaan Dana kapitasi JKN yang terdapat dalam kewenangannya.

Peserta adalah setiap orang, termasuk orang asing yang bekerja paling singkat 6 (enam) bulan di Indonesia, yang telah membayar iuran. Peserta JKN terdiri atas Peserta penerima bantuan iuran (PBI) dan peserta non penerima bantuan iuran (Non PBI). ${ }^{8}$

Pertama, peserta penerima bantuan iuran (PBI). Dalam Peraturan Pemerintah Nomor 101 Tahun 2012 tentang Penerima Bantuan Iuran Jaminan Kesehatan, di antaranya disebutkan bahwa: (1) Kriteria fakir miskin dan orang tidak mampu ditetapkan oleh Menteri Sosial setelah berkoordinasi dengan Menteri dan/atau pimpinan lembaga terkait.

(2) Hasil pendataan fakir miskin dan orang tidak

${ }^{8}$ TNP2K (Tim Nasional Percepatan Penanggulangan Kemiskinan), "Program Penanggulangan Kemiskinan", Sekretariat Tim Nasional Percepatan Penanggulangan Kemiskinan Grand Kebon Sirih Lt.4, Jl. Kebon Sirih Raya No. 35, Jakarta Pusat TNP2K 2014. mampu yang dilakukan oleh lembaga yang menyelenggarakan urusan pemerintahan di bidang statistik (BPS) diverifikasi dan divalidasi oleh Menteri Sosial untuk dijadikan data terpadu. (3) Data terpadu yang ditetapkan oleh Menteri Sosial dirinci menurut provinsi dan kabupaten/kota dan menjadi dasar bagi penentuan jumlah nasional PBI Jaminan Kesehatan. (4) Menteri Kesehatan mendaftarkan jumlah nasional PBI Jaminan Kesehatan sebagai peserta program Jaminan Kesehatan kepada BPJS Kesehatan.

Untuk tahun 2014, peserta PBI JKN berjumlah 86,4 juta jiwa yang datanya mengacu pada basis data terpadu (BDT) hasil pendataan program perlindungan sosial (PPLS) yang dilaksanakan pada tahun 2011 oleh BPS dan dikelola oleh sekretariat tim nasional percepatan penanggulangan kemiskinan (TNP2K). Namun demikian, mengingat sifat data kepesertaan yang dinamis, di mana terjadi kematian, bayi baru lahir, pindah alamat, atau peserta adalah PNS, maka Menteri Kesehatan mengeluarkan Surah Edaran Nomor 149 tahun 2013 yang memberikan kesempatan kepada Pemerintah Daerah untuk mengusulkan peserta pengganti yang jumlahnya sama dengan jumlah peserta yang diganti. Adapun peserta yang dapat diganti adalah mereka yang sudah meninggal, merupakan PNS/ TNI/POLRI, pensiunan PNS/TNI/POLRI, tidak diketahui keberadaannya, atau peserta memiliki jaminan kesehatan lainnya. Di samping itu, sifat dinamis kepesertaan ini juga menyangkut perpindahan tingkat kesejahteraan peserta, sehingga banyak peserta yang dulu terdaftar sebagai peserta Jamkesmas saat ini tidak lagi masuk ke dalam BDT.

Kedua, peserta non penerima bantuan iuran (Non PBI). Peserta Non PBI dalam JKN adalah setiap orang yang tidak tergolong fakir miskin dan orang tidak mampu, yang membayar iurannya secara sendiri ataupun kolektif ke BPJS Kesehatan. Peserta Non PBI JKN terdiri atas: (1) Peserta penerima upah dan anggota keluarganya, yaitu Setiap orang yang bekerja pada pemberi kerja dengan menerima gaji atau upah, antara lain Pegawai Negeri Sipil, Anggota TNI, Anggota Polri, Pejabat Negara, Pegawai Pemerintah Non Pegawai Negeri Sipil, Pegawai Swasta, dan Pekerja lain yang memenuhi kriteria pekerja penerima upah. (2) Pekerja bukan penerima upah dan anggota keluarganya, yaitu setiap orang yang bekerja atau berusaha atas risiko sendiri, antara lain pekerja di luar hubungan kerja atau pekerja mandiri, dan lain sebagainya. (3) Bukan pekerja penerima dan anggota keluarganya, setiap orang yang tidak bekerja tapi 
mampu membayar iuran Jaminan Kesehatan, antara lain Investor, Pemberi kerja, Penerima pensiun, Veteran, Perintis kemerdekaan, dan bukan pekerja lainnya yang memenuhi kriteria bukan pekerja penerima upah.

Dalam memilih kelas perlu diketahui terutama bagi yang Non-PBI (bukan penerima bantuan iuran jaminan kesehatan), yaitu: ${ }^{9}$ Kelas 1/ orang $=\operatorname{Rp} 59.500 /$ bulan; Kelas $2 /$ orang $=R p$ 42.500/bulan; Kelas 3/ orang $=R p$ 25.500/bulan.

\section{Hukum BPJS Kesehatan}

Fatwa Majelis Ulama Indonesia (MUI) yang memutuskan bahwa penyelenggaraan Badan Penyelenggara Jaminan Sosial (BPJS) Kesehatan tidak sesuai syariat (hukum Islam), menimbulkan polemik. Namun MUI sebagai lembaga swadaya masyarakat yang mewadahi ulama, zuama, dan cendekiawan Muslim di Indonesia untuk membimbing, membina, dan mengayomi kaum muslimin di seluruh Tanah Air itu, tentu tidak serta-merta mengeluarkan fatwa tersebut. Fatwa atau keputusan MUI itu dikeluarkan melalui Ijtimak Ulama Komisi Fatwa se-Indonesia V yang diselenggarakan di Pondok Pesantren at-Tauhidiyah, Cikura, Tegal, Jawa Tengah pada tanggal 19-22 Syảban 1436 H/7-10 Juni 2015.

Fatwa terkait BPJS Kesehatan ini tercantum di keputusan Komisi B 2, terkait masalah fikih kontemporer, tentang panduan jaminan kesehatan nasional dan BPJS Kesehatan. Dalam keputusan itu dideskripsikan bahwa MUI memperhatikan program termasuk modus transaksional yang dilakukan oleh BPJS, khususnya BPJS Kesehatan, dari perspektif ekonomi Islam dan fikih muamalah.

Merujuk pada fatwa Dewan Syariah NasionalMajelis Ulama Indonesia (DSN-MUI) dan beberapa literatur, tampaknya bahwa secara umum program BPJS Kesehatan belum mencerminkan konsep ideal jaminan sosial dalam Islam. Terlebih lagi jika dilihat dari hubungan hukum atau akad antarpihak. Dalam hal terjadi keterlambatan pembayaran iuran untuk pekerja penerima upah, maka dikenakan denda administratif sebesar $2 \%$ per bulan dari total iuran yang tertunggak paling banyak untuk waktu tiga bulan. Denda tersebut dibayarkan bersamaan dengan total iuran yang tertunggak oleh pemberi kerja. Sementara keterlambatan pembayaran iuran untuk peserta bukan

\footnotetext{
${ }^{9}$ Radit Yudistia, "Panduan Cara Daftar BPJS Kesehatan Online dan Syarat-syaratnya”, 2014.
}

penerima upah dan bukan pekerja dikenakan denda keterlambatan sebesar $2 \%$ per bulan dari total iuran yang tertunggak paling banyak untuk waktu enam bulan yang dibayarkan bersamaan dengan total iuran yang tertunggak. ${ }^{10}$

Dari deskripsi tersebut, MUI kemudian merumuskan beberapa masalah. ${ }^{11}$ Pertama, gharâr (ketidakjelasan) bagi peserta dalam menerima hasil dan bagi penyelenggara dalam menerima keuntungan. Kedua, mukhatharah (untung-untungan), yang berdampak pada unsur maysir (judi). Ketiga, riba fadhl (kelebihan antara yang diterima dan yang dibayarkan), termasuk denda karena keterlambatan.

Pertama, peserta bayar premi bulanan, namun tidak jelas berapa jumlah yang akan diterima. Bisa lebih besar, bisa kurang. Di situlah unsur gharâr (ketidak jelasan) dan untung-untungan. Ketika gharâr itu sangat kecil, mungkin tidak menjadi masalah. Karena hampir dalam setiap jual beli, ada unsur gharâr, meskipun sangat kecil. Dalam asuransi kesehatan BPJS, tingkatannya nasional. Artinya, perputaran uang di sana sangat besar. Bisa bayangkan ketika sebagian besar WNI menjadi peserta BPJS, dana ini bisa mencapai angka triliyun. Jika dibandingkan untuk biaya pemeliharaan kesehatan warga, akan sangat jauh selisihnya, disana terdapat unsur gharâr-nya sangat besar. Dari Abû Hurayrah Ra, mengatakan:

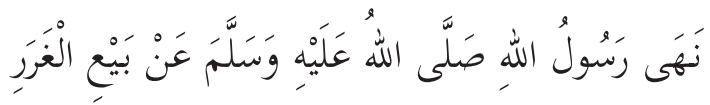

Rasulullah Saw .melarang jual beli gharâr. (Hr. Muslim 1513). ${ }^{12}$

Gharâr artinya keraguan, tipuan, atau tindakan yang bertujuan untuk merugikan pihak lain. ${ }^{13}$ Gharâr dalam objek transaksinya terbagi delapan macam. ${ }^{14}$ Pertama, ketidakjelasan jenis objek transaksi (الجهالة في جنس المعقودعليه). Mengetahui jenis objek akad secara jelas adalah syarat sahnya jual beli. Maka jual beli yang objeknya tidak diketahui tidak sah hukumnya karena terdapat gharâr yang banyak di dalamnya. ${ }^{15}$

Kedua, ketidakjelasan dalam macam objek transaksi

${ }^{10}$ Ricardo, "Di Balik Keluarnya Fatwa MUI BPJS Kesehatan Tak Sesuai Hukum Islam", Berita Harian JPNN, PT. Jawa Pos National Network, 2015.

11 Ammi Nur Baits, "Alasan MUI Melarang BPJS", Dewan Pembina Konsultasi Syariah, Tahun 2015.

${ }^{12}$ Al-Muslim, Shâhîh $\underline{h}$ Muslim, Dâr al-Fikr Bayrut, t.t. h. 1513.

${ }^{13}$ M. Ali Hasan, Berbagai Macam Transaksi Dalam Islam, (Jakarta: Rajawali Pers, 2010), h. 147.

${ }^{14}$ Wardah, "Gharar", makalah, IAIN Antasari Banjarmasin tahun 2010.

${ }^{15}$ Nasrun Harun, Figh Muamalah, (Jakarta: Gaya Media Pratama, 2011), h. 137. 
(الحهالة في نوع المعقودعليه). Gharâr dalam macam objek akad dapat menghalangi sahnya jual beli sebagaimana terjadi dalam jenis objek akad. Tidak sahnya akad seperti ini karena mengandung unsur ketidakjelasan dalam objeknya. ${ }^{16}$

Ketiga, ketidakjelasan dalam sifat dan karakter objek transaksi (الجهالة في الصفة المعقودعليه). Terdapat perbedaan pendapat di kalangan ulama fikih tentang persyaratan dalam menyebutkan sifat-sifat objek transaksi dalam jual beli, akan tetapi mayoritas ulama fikih berpendapat untuk mensyaratkannya.

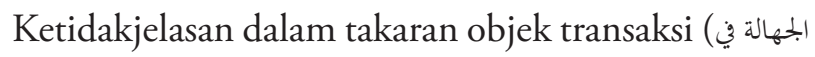
(القدر المعقودعليه Tidak sah jual beli sesuatu yang kadarnya tidak diketahui, baik kadar komoditinya maupun kadar harga atau uangnya.

Kelima, ketidakjelasan dalam zat objek transaksi Ketidaktahuan dalam zat objek transaksi adalah bentuk dari gharâr yang terlarang. Hal ini karena dzat dari komoditi tidak diketahui, walaupun jenis, macam, sifat, dan kadarnya diketahui, sehingga berpotensi untuk menimbulkan perselisihan dalam penentuan.

Keenam, ketidakjelasan dalam waktu objek transaksi (الجهالة في الزمن المعقودعليه). Jual beli tangguh (kredit), jika tidak dijelaskan waktu pembayarannya, maka ia termasuk jual beli gharâr yang terlarang.

Ketujuh, ketidakjelasan dalam penyerahan objek transaksi (عدم الفدرة على تسليم). Kemampuan menyerahkan objek transaksi adalah syarat sahnya dalam jual beli.

Kedelapan, objek transaksi yang spekulatif Gharâr yang dapat mempengaruhi sahnya jual beli adalah tidak adanya (mádum) objek transaksi. Yaitu keberadaan objek transaksi bersifat spekulatif.

Solusi agar tidak terjadi gharâr (peserta bayar premi bulanan, namun tidak jelas berapa jumlah yang akan diterima, bisa lebih besar, bisa kurang), ini dengan tabungan sukarela sejak pembayaran premi yang diniatkan peserta dalam akad. Sehingga tidak mengklaim yang membayar premi lebih banyak akan menerima besar dan sebaliknya dengan tabungan sukarela itu sebagai infak untuk membantu sesama tanpa melihat besar kecilnya dari premi yang diterima.

Kedua, secara perhitungan keuangan bisa jadi untung, bisa jadi rugi. Tidak menyebut peserta BPJS

${ }^{16}$ Syamsul Anwar, Hukum Perjanjian Syariah: Studi tentang Teori Akad dalam Figh Muamalah, (Jakarta: Rajawali Pers, 2012), h. 191. yang sakit berarti untung, sebaliknya ketika sehat berarti rugi. Namun dalam perhitungan keuangan, yang diperoleh peserta ada 2 kemungkinan, bisa jadi untung, bisa jadi rugi. Sementara kesehatan peserta yang menjadi taruhannya.Jika dia sakit, dia bisa mendapatkan klaim dengan nilai yang lebih besar dari pada premi yang dia bayarkan.Karena pertimbangan ini, MUI menyebutnya, ada unsur maysir (judi).

Dalam Alquran, kata maysir disebutkan sabanyak tiga kali, yaitu dalam surah al-Baqarah (2) ayat 219, surah al-Mâidah (5) ayat 90 dan ayat 91. Ketiga ayat ini menyebutkan beberapa kebiasaan buruk yang berkembang pada masa jahiliyah, yaitu khamar, almaysir, al-anshâb (berkorban untuk berhala), dan alazlâm (mengundi nasib dengan menggunakan panah). Penjelasan tersebut dilakukan dengan menggunakan jumlah khabariyyah dan jumlah insya iyyah. Dengan penjelasan tersebut, sekaligus Alquran sesungguhnya menetapkan hukum bagi perbuatan-perbuatan yang dijelaskan itu. Di dalam surah al-Baqarah (2) ayat 219 disebutkan sebagai berikut:

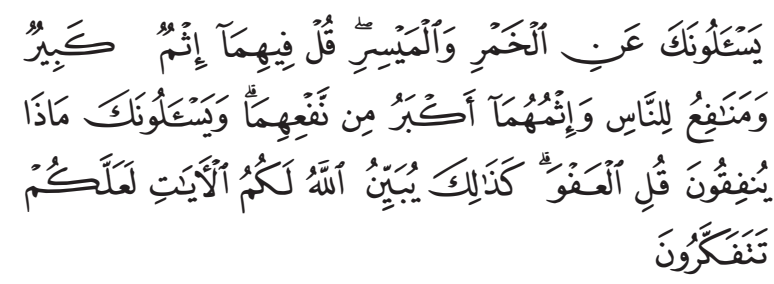

Mereka bertanya kepadamu tentang khamar dan judi. Katakanlah, "Pada keduanya terdapat dosa yang besar dan beberapa manfaat bagi manusia, tetapi dosa keduanya lebih besar dari manfaatnya”. dan mereka bertanya kepadamu apa yang mereka nafkahkan. Katakanlah, "yang lebih dari keperluan.” Demikianlah Allah menerangkan ayat-ayat-Nya kepadamu supaya kamu berpikir". ${ }^{17}$

Sehubungan dengan judi, ayat ini merupakan ayat pertama yang diturunkan untuk menjelaskan keberadaannya secara hukum dalam pandangan Islam. Setelah ayat ini, menurut al-Qurthubî kemudian diturunkan ayat yang terdapat di dalam surah al-Mẩidah ayat 91 (tentang khamar ayat ini merupakan penjelasan ketiga setelah surah al-Nisâ' ayat 43). Terakhir Allah menegaskan pelarangan judi dan khamar dalam surah al-Mầidah ayat 90 .

Solusi agar tidak terjadi unsur judi, perhitungan keuangan bisa jadi untung, bisa jadi rugi. Tidak menyebut peserta BPJS yang sakit berarti untung, sebaliknya ketika sehat berarti rugi. Hendaknya pengelolaan premi yang dibayarkan peserta BPJS terbagi

\footnotetext{
${ }^{17}$ Hasbi Al-Shiddieqy, Al-Qur'an dan Terjemahnya, Departemen Agama RI., (Jakarta: PT. Tanjung Mas Inti Semarang, 2012), h. 109.
} 
tiga alokasi dana, yaitu dana tabarru' (sukarela/kebajikan), tabungan (investasi) dan upah (ujrah) bagi pengelola BPJS. Dengan pembagian dana ini alokasinya jelas, bagi peserta yang sakit biayanya diambil dari dana tabarru' yang diberikan peserta secara sukarela dengan prinsif ta'âwun (tolong menolong). Dana investasi ini merupakan dana tabungan dari premi yang dibayarkan setiap bulan dan dapat diambil sesuai waktu yang ditentukan dalam akad. Sedangkan ujrah ini sebagai upah bagi pengelola BPJS yang dananya dari premi yang dibayarkan peserta yang besarannya sudah ditentukan dalam akad sesuai dengan kesepakatan. Jadi perhitungan dan pembagian dana ini jelas tidak ada unsur judi karena dibagi sesuai peruntukannya dengan tidak tarik menarik antara yang sakit dan yang sehat.

Ketiga, ketika klaim yang diterima peserta BPJS lebih besar dari premi yg dibayarkan, hal tesrebut mengandung unsur riba. Demikian pula, ketika terjadi keterlambatan peserta dalam membayar premi, BPJS menetapkan denda yang juga termasuk riba. Riba secara literal berarti bertambah, berkembang, atau tumbuh. ${ }^{18}$ Menurut istilah teknis, riba berarti pengambilan tambahan dari harta pokok atau modal secara batil. Ada beberapa pendapat dalam menjelaskan riba, namun secara umum terdapat benang merah yang menegaskan bahwa riba adalah pengambilan tambahan, baik dalam transaksi jual beli maupun pinjam-meminjam secara batil atau bertentangan dengan prinsip muamalah dalam Islam. ${ }^{19}$

Macam macam riba, yaitu: ${ }^{20}$ (a) Riba fadhli, yaitu riba dengan sebab tukar-menukar benda, barang sejenis (sama) dengan tidak sama ukuran jumlahnya. (b) Riba qardhi, yaitu riba yang terjadi karena adanya proses utang-piutang atau pinjam-meminjam dengan syarat keuntungan (bunga) dari orang yang meminjam atau yang berhutang. (c) Riba nasìah, ialah tambahan yang disyaratkan oleh orang yang mengutangi dari orang yang berutang sebagai imbalan atas penangguhan (penundaan) pembayaran utangnya. d). Riba Yad, yaitu riba dengan berpisah dari tempat akad jual beli sebelum serah terima antara penjual dan pembeli.

${ }^{18}$ M. Umer Chapra, Sistem Moneter Islam, diterjemahkan: Ikhwan Abidin Basri, The Islamic Faoundation, (Jakarta: Gema Insani Press dan Tazkia Cendekia, 2010), h. 22.

19 Muhammad Syafi'i Antonio, Bank Syariah Dari Teori ke Praktek, (Jakarta: Gema Insani, 2011), h. 37.

${ }^{20}$ Masjfuk Zuhdi, Masail Fiqhiyah, (Jakarta: CV. Haji Masagung, 2009), h. 103. Lihat Muhammad Syafi'i Antonio, Bank Syariah Dari Teori ke Praktek, (Jakarta:Gema Insani, 2011), Lihat Muh Zuhri, Riba dalam Al-Qur'an dan Masalah Perbankan, (Jakarta: Raja Grafindo Persada, 2008).
Alasan pengharaman riba, yaitu: ${ }^{21}$ Pertama, karena riba berarti mengambil harta si peminjam secara tidak adil. Kedua, dengan riba, seseorang akan malas bekerja dan berbisnis karena dapat duduk-duduk tenang sambil menunggu uangnya berbunga. ketiga, riba akan merendahkan martabat manusia dengan bunga tinggi dengan hutangnya. keempat, riba akan membuat yang kaya bertambah kaya dan si miskin bertambah miskin.

Melihat pembahasan tentang riba di atas ketika klaim yang diterima peserta BPJS lebih besar dari premi yg dibayarkan, hal tersebut mengandung unsur riba yang termasuk pada riba fadhlî. Sedangkan ketika terjadi keterlambatan peserta dalam membayar premi, BPJS menetapkan denda yang juga termasuk riba nasîah. Solusinya pengelolaan BPJS ketika terjadi kalim peserta yang diterima lebih besar dari premi yang dibayarkan, pembayarannya diambil dari dana tabarru' (sukarela/ kebajikan) agar tidak terjadi riba fadhlî (tidak sama uang yang diterima dengan premi yang dibayarkan) dengan prinsip syariah al-takmin al-ta’awunî (asuransi sosial). Demikian denda yang dikenakan bagi peserta BPJS, dengan dana tabarru' tersebut akan dapat tertalangi keterlambatan pembayaran tersebut tanpa meminta denda kepada peserta BPJS, sehingga tidak terhindar dari riba nasiah.

\section{Penutup}

Sistem pengelolaan BPJS memerlukan unit syariah untuk menjalankan sistem operasinya sesuai dengan prinsip syariah. Ketika program jaminan sosial dikelola sebuah lembaga, seperti BPJS, maka prinsip-prinsip syariah al-takmîn al-taầwunî seharusnya diterapkan. Untuk menerapkan prinsip itulah diperlukan Unit Syariah.

Solusi agar tidak terjadi gharâr dengan tabungan sukarela sejak pembayaran premi yang diniatkan peserta dalam akad. Sehingga tidak mengklaim yang membayar premi lebih banyak akan menerima besar dan sebaliknya dengan tabungan sukarela itu sebagai infak untuk membantu sesama tanpa melihat besar kecilnya dari premi yang diterima.

Solusi agar tidak terjadi unsur judi, perhitungan keuangan bisa jadi untung, bisa jadi rugi. Tidak menyebut peserta BPJS yang sakit berarti untung, sebaliknya ketika sehat berarti rugi. Hendaknya pengelolaan premi yang dibayarkan peserta BPJS terbagi tiga alokasi dana, yaitu

21 Adiwarman aswar karim, Ekonomi Islam Suatu Kajian Kontemporer, (Jakarta: Gema Insani press, 2012), h. 71. Lihat juga A. M. Sadeq, "Factor Pricing and Income Distribution from An Islamic Perspective" yang dipublikasikan dalam Journal of Islamic Economics, 2013, h. 27-28. 
dana tabarru', tabungan (investasi) dan upah (ujrah) bagi pengelola BPJS. Dengan pembagian dana ini alokasinya jelas, bagi peserta yang sakit biayanya diambil dari dana tabarru' yang diberikan peserta secara sukarela dengan prinsif ta’âwun. Dana investasi ini merupakan dana tabungan dari premi yang dibayarkan setiap bulan dan dapat diambil sesuai waktu yang ditentukan dalam akad. Sedangkan ujroh ini sebagai upah bagi pengelola BPJS yang dananya dari premi yang dibayarkan peserta yang besarannya sudah ditentukan dalam akad sesuai dengan kesepakatan. Jadi perhitungan dan pembagian dana ini jelas tidak ada unsur judi karena dibagi sesuai peruntukannya dengan tidak tarik menarik antara yang sakit dan yang sehat.

Solusi tentang riba, ketika klaim yang diterima peserta BPJS lebih besar dari premi yg dibayarkan, hal tersebut mengandung unsur riba dan termasuk pada riba fadhlî. Sedangkan ketika terjadi keterlambatan peserta dalam membayar premi, BPJS menetapkan denda yang juga termasuk riba nasî'ah. Solusinya pengelolaan BPJS ketika terjadi kalim peserta yang diterima lebih besar dari premi yg dibayarkan, pembayarannya diambil dari dana tabaru' (sukarela/ kebajikan) agar tidak terjadi riba fadhlì (tidak sama uang yang diterima dengan premi yang dibayarkan) dengan prinsip syariah al-takmin al-tâ̂wunî (asuransi sosial). Demikian denda yang dikenakan bagi peserta BPJS, dengan dana tabarru' tersebut akan dapat tertalangi keterlambatan pembayaran tersebut tanpa meminta denda kepada peserta BPJS, sehingga tidak terhindar dari riba nasîah.[]

\section{Pustaka Acuan}

Anonymous, Peraturan Presiden Nomor 32 Tahun 2014 Tentang Pengelolaan dan Pemanfaatan Dana kapitasi Jaminan Kesehatan Nasional, Tahun 2014. Undang-Undang Dasar RI. Tahun 1945 Tahun 2013.

Undang-Undang Republik Indonesia Nomor 40 Tahun 2004 Tentang Sistem Jaminan Sosial Nasional, Tahun 2011.

, Undang-Undang Republik Indonesia Nomor 40 Tahun 2004 Tentang Sistem Jaminan Sosial Nasional. Tahun 2012.

Antonio, Muhammad Syafi'i, Bank Syariah Dari Teori ke Praktik, Jakarta:Gema Insani, 2011.

Anwar, Syamsul, Hukum Perjanjian Syariah: Studi tentang Teori Akad dalam Fikih Muamalah, Jakarta: Rajawali Pers, 2012.
Baits, Ammi Nur, "Alasan MUI Melarang BPJS", Dewan Pembina Konsultasi Syariah, Tahun 2015.

BPJS “BPJS Kesehatan", Jln. Let. Jend. Suprapto Cempaka Putih Jakarta Pusat, 2014.

Chapra, M. Umer, Sistem Moneter Islam, diterjemahkan: Ikhwan Abidin Basri, The Islamic Faoundation, Jakarta: Gema Insani Press dan Tazkia Cendekia, 2010.

Dakhi, Rahmat Alyakin, "Analisis Kebijakan Jaminan Kesehatan Nasional (JKN)", Program Doktor Ilmu Kesehatan Masyarakat Fakultas Kesehatan Masyarakat Universitas Sumatera Utara Medan 2014.

Feny, Author, "Syarat Mendapatkan Kartu Perlindungan Sosial”, Dinas Tenaga Kerja dan Sosial/Disnakersos (Gedung Dibaleka II Komplek Balaikota Depok Lantai 8, Jl. Margonda Raya No. 54 Depok, 2013.

Hartati, Ita, "Dana kapitasi BPJS Kesehatan: Pelaksanaan dan Pertanggungjawabannya”, Artikel, Balai Diklat Keuangan Makassar, 2014.

Harun, Nasrun, Fikih Muamalah, Jakarta: Gaya Media Pratama, 2011.

Hasan, M. Ali, Berbagai Macam Transaksi Dalam Islam, Jakarta: Rajawali Pers, 2010.

Karim, Adiwarman Aswar karim, Ekonomi Islam Suatu Kajian Kontemporer, Jakarta: Gema Insani press, 2012.

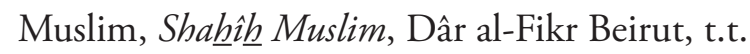

Ricardo, "Di Balik Keluarnya Fatwa MUI BPJS Kesehatan Tak Sesuai Hukum Islam", Berita Harian JPNN. PT. Jawa Pos National Network, 2015.

Sadeq, A.M., "Factor Pricing and Income Distribution from An Islamic Perspective" yang dipublikasikan dalam Journal of Islamic Economics, 2013.

Shiddieqy, Ash- Hasbi, Alquran dan Terjemahnya, Departemen Agama RI., Jakarta: PT. Tanjung Mas Inti Semarang, 2012.

Tijan, Antia, "Analisa Kebijakan Undang-undang Implementasi BPJS 1 Januari 2014", Magister Ilmu Keperawatan Universitas Indonesia, 2014.

TNP2K (Tim Nasional Percepatan Penanggulangan Kemiskinan), "Program Penanggulangan Kemiskinan", TNP2K 2014.

Udzma, Rizka Syafaatul, "Evaluasi Jaminan Kesehatan Nasional dalam Upaya Peningkatan Mutu Pelayanan Kesehatan di Indonesia”, Program Studi Ilmu 
Farmasi Sekolah Tinggi Ilmu Kesehatan Ngudi Waluyo, 2014.

Wardah, "Gharâr", Makalah, IAIN Antasari Banjarmasin Tahun 2010.

Yudistia, Radit, "Panduan cara daftar BPJS kesehatan online dan syarat-syaratnya, Artikel, Tahun 2014.
Zuhdi, Masjfuk, Masail Fikihiyah, CV. Haji Masagung, Jakarta, 2009.

Zuhri, Muh, Riba dalam Alquran dan Masalah Perbankan, Jakarta: Raja Grafindo Persada, 2008. 